\title{
Raphaël Lemkin, creator of the concept of genocide: a world history perspective $^{1}$
}

\author{
John Docker
}

Genocide is one of those rare concepts whose author and inception can be precisely specified and dated. The term was created by the brilliant PolishJewish and later American jurist Raphaël Lemkin (1900-59) in 'Genocide' in his book Axis Rule in Occupied Europe: Laws of occupation, analysis of government, proposals for redress, published in the United States in $1944 .^{2}$ Lemkin was also the prime mover in the discussions that led to the 1948 UN Convention on the Prevention and Punishment of the Crime of Genocide. The concept was immediately recognised worldwide as of contemporary significance and future importance, for it called attention to humanity at its limits. It is a major concept in international law, for its framework of group experience and rights challenges both a stress on the individual as the subject of law and the exclusive jurisdiction of modern nation-states. ${ }^{3}$

Lemkin as an intellectual figure and the concept of genocide have been a preoccupying interest for me since 2001 when I co-edited a special series of essays for the journal Aboriginal History called "Genocide"? Australian Aboriginal history in international perspective'. ${ }^{4}$ The spectre of genocide as a feature of Australian history in relation to its Indigenous peoples had, only a few years before, been raised by the Australian Human Rights Commission's 1997 Bringing Them Home report, which argued that the Aboriginal child-removal practices

\footnotetext{
1 My thanks to Ned Curthoys, of the Research School of Humanities and the Arts, The Australian National University, for inviting me to give a lecture on Lemkin in the Key Thinker series that he convenes; I gave the lecture at Old Canberra House on 27 May 2008; this essay is a revised and updated version.

2 Lemkin, R. 1944, Axis Rule in Occupied Europe: Laws of occupation, analysis of government, proposals for redress, Columbia University Press, New York, ch. IX, pp. 79-95.

3 Parts of this essay appeared in earlier form in Curthoys, Ann and Docker, John 2008, 'Defining genocide', in Dan Stone (ed.), The Historiography of Genocide, Palgrave Macmillan, London, pp. 9-41. Concerning the importance of what she felicitously refers to as the 'ontology of the group' in Lemkin's conceptions of history and law: cf. Benhabib, Seyla 2009, 'International law and human plurality in the shadow of totalitarianism: Hannah Arendt and Raphael Lemkin', Constellations, vol. 16, no. 2, pp. 339-42 (the reference to 'ontology of the group' is on p. 333, also p. 340).

4 Aboriginal History, vol. 25 (2001). Apart from Ann Curthoys and John Docker ('Introduction - genocide: definitions, questions, settler-colonies'), the essays are by Bain Attwood, Tony Barta, Larissa Behrendt, Anna Haebich, Rosanne Kennedy, Andrew Markus, A. Dirk Moses, Deborah Rose and Colin Tatz.
} 
in the nineteenth and twentieth centuries fell within the definition of genocide used in the 1948 UN Genocide Convention. ${ }^{5}$ In 2003, Ann Curthoys and I researched Lemkin's papers in the American Jewish Historical Society in New York and the New York Public Library, where we were especially eager to pursue the suggestions in his definition linking genocide with settler colonialism. ${ }^{6}$ I think that Australian scholars are at the forefront of world genocide studies because historical investigation of settler colonialism is so intense, sustained and interrogative in Australia. ${ }^{7}$ Inspired by Lemkin's work, the new genocide studies asks: are settler colonies inherently or constitutively genocidal? ${ }^{8}$ And, if so, what does this say of the ethical character of post-1492 European settler colonialism and empires? After such knowledge, what honour? ${ }^{9}$

My essay will be in two parts. Part one will offer a sketch of Lemkin's life, outlining his ideas about genocide in his published and unpublished writings. My approach is influenced by Hannah Arendt's Men in Dark Times, which says we can best understand a thinker in terms of biography, sensibility, anecdote and social genealogy. ${ }^{10}$ I am also influenced by Janet Abu-Lughod's world-history approach. Abu-Lughod suggests that the writing of significant historical narrative entails a number of qualities: it should be conceived in an anti-Euro-centric spirit, it should involve a 'synthetic imagination or vision' and it should engage in what the philosopher Hans Gadamer in Truth and Method refers to as a capacity for 'reflexivity and self-conscious awareness'. Historical reflection should also include an element that is extremely personal; indeed, Abu-Lughod values a mode of personal vision that is inspired by eccentricity and idiosyncrasy - the kind of vision, she feels, that leads to the finding of a particular pattern in history. ${ }^{11}$

5 Cf. Moses, A. Dirk (ed.) 2004, Genocide and Settler Society: Frontier violence and stolen Indigenous children in Australian history, Berghahn, New York and Oxford.

6 Our genocide studies colleague Dirk Moses has also researched the Lemkin Papers in New York, as well as in The Jacob Rader Marcus Centre of the American Jewish Archives (JRMCAJA), 3101 Clifton Avenue, Cincinnati, Ohio. In his introductory essay, 'Empire, colony, genocide: keywords and the philosophy of history' (in Moses, A. Dirk [ed.] 2008, Empire, Colony, Genocide: Conquest, occupation, and subaltern resistance in world history, Berghahn, New York and Oxford, pp. 20-1), Moses quotes from a remarkable unpublished draft manuscript, 'Hitler case-outline', in the Cincinnati Lemkin Papers, in order to discuss Lemkin's notions of Nazism and the Holocaust in relation to the linking of genocide with colonisation and empire in his definition. 7 Cf. Curthoys, Ann, Genovese, Ann and Reilly, Alexander 2008, Rights and Redemption: History, law, and indigenous people, UNSW Press, Sydney, passim.

8 Cf. Stone, Dan (ed.) 2008, The Historiography of Genocide, Palgrave Macmillan, London; and Moses, Empire, Colony, Genocide.

9 Cf. Docker, John 2008, The Origins of Violence: Religion, history and genocide, Pluto, London, ch. 7, pp. $161-87$.

10 Arendt, Hannah 1970, Men in Dark Times, Jonathan Cape, London; cf. Curthoys, Ned 2002, 'Hannah Arendt and the politics of narrative', JNT: Journal of narrative theory, vol. 32, no. 3, pp. 348-70.

11 Abu-Lughod, Janet 1995, 'The world-system perspective in the construction of economic history', History and Theory, vol. 34, no. 2, pp. 91-6. Cf. Curthoys, Ann and Docker, John 2010, Is History Fiction?, Second edition, UNSW Press, Sydney, ch. 12, pp. 247-9. 
In part two, I offer some possible criticisms of Lemkin. In particular, a question mark hangs over his attitude to African Americans and indeed to Africa and Africans, raising disturbing questions that also haunt Arendt scholarship. I wish in turn to bring to the fore a more general problem: European or Europeanderived intellectuals, so committed to cosmopolitanism and inclusive notions of humanity, yet revealing a distressingly familiar Euro-centric failure of critical consciousness and reflexivity.

\section{Raphaël Lemkin's life, contexts and the concept of 'genocide'}

Lemkin was born on 24 June 1900 in Bezwodne, a village near Wolkowysk (now Vaulkovisk), a small city in what is now Belarus. In his unfinished autobiography, 'Totally unofficial man', Lemkin recalls that from childhood he was stirred by historical accounts of extermination. He read about the destruction of the Christians by Nero; the Mongols overrunning Russia, Poland, Silesia and Hungary in 1241; the persecution of Jews in Russia by Tsar Nicholas I; the destruction of the Moors in Spain; the devastation of the Huguenots. He confides that from an early age he took a special delight in being alone, so that he could feel and think without outer disturbances, and that loneliness became the essential condition of his life. ${ }^{12}$

Lemkin studied philology at the University of Lvov, then decided on a career in law. He gained his doctorate of laws in 1926 from Lvov and in the next year studied in Heidelberg, Rome and Paris, but received no further degrees. He then moved to Warsaw, where he became a public prosecutor. In 1933, the year of Hitler's election to government in Germany, Lemkin sent a paper to a League of Nations conference in Madrid on the unification of penal law. He proposed the creation of the crimes of barbarity and vandalism as new offences against the law of nations. Acts of barbarity-ranging from massacres and pogroms to the ruining of a group's economic existence - undermine the fundamental basis of an ethnic, religious or social collectivity. Acts of vandalism concern the destruction of the cultural heritage of a collectivity as revealed in the fields of science, arts and literature. Lemkin argued that the destruction of any work of art of any nation must be regarded as an act of vandalism directed against 'world culture'. Lemkin always regretted that the 1933 conference did not enact his proposals in international law. He felt that if they had been ratified by the 37 countries represented at Madrid, the new laws could have inhibited the rise of

12 Lemkin, R. 2002, 'Totally unofficial man', in S. Totten and S. L. Jacobs (eds), Pioneers of Genocide Studies, Transaction Publishers, New Brunswick, NJ, pp. 366-9, 370, 379-80, 387-92. 
Nazism by declaring that attacks on national, religious and ethnic groups were international crimes and that the perpetrators of such crimes could be indicted whenever they appeared on the territory of one of the signatory countries. ${ }^{13}$

In 1939, Lemkin fled Poland and reached Stockholm in Sweden, where he did extensive research on Nazi occupation laws throughout Europe. On 18 April 1941, he arrived in the United States via Japan. He thought help for European Jewry, including his own family, could come only from the United States, which he saw as a nation born out of moral indignation against oppression and a beacon of freedom and human rights for the rest of the world. Yet he also records that as he travelled by train to take up a teaching appointment at Duke University, he saw on the station at Lynchburg, Virginia, toilet signs saying 'For whites' and 'For colored'. Lemkin says that he asked the 'Negro porter if there were indeed special toilets for Negroes', but was met with a puzzled look mixed with hostility; later, after 17 years in the United States, he understood that the porter must have thought he was making fun of him. ${ }^{14}$ An ambivalence about the moral history of the United States remained to his last days - revealed especially in his unpublished papers.

What was notable about Lemkin's 1933 proposals concerning barbarity and vandalism was the breadth of his formulations. In similar spirit, 11 years later, chapter nine of Axis Rule in Occupied Europe proposed his new concept of 'genocide', deriving the term from the Greek word 'genos' (tribe, race) and the Latin 'cide' (as in tyrannicide, homicide, fratricide). What is really important to stress is how wide-ranging Lemkin's definition is - far more wide-ranging than later definitions proffered in the decades that followed, especially definitions by North American sociologists from the 1970s to the 1990s who saw the Holocaust as paradigmatic of genocide. The North American sociologists narrowed genocide to intentional state-directed mass death. ${ }^{15}$

As Lemkin explains in the now famous chapter nine, genocide is to be regarded as composite and manifold; it signifies a coordinated plan of different actions aimed at the destruction of the essential foundations of life of a group. Such actions can but do not necessarily involve mass killing; they can be incremental, involving aspects that are cultural, political, social, legal, intellectual, spiritual, economic, biological, physiological, religious and moral. Such actions involve

13 Ibid., p. 373; Lemkin, Axis Rule in Occupied Europe, pp. xiii, 92-3; Lemkin, R. 1947, 'Genocide as a crime under international law', American Journal of International Law, vol. 41, no. 1, p. 147.

14 Lemkin, 'Totally unofficial man', pp. 378-81, 385.

15 Cf. Curthoys and Docker, 'Defining genocide', pp. 26-32. 
issues of health, food and nourishment, of family life and care of children and of birth as well as death. Such actions involve considerations of the honour and dignity of peoples and the future of humanity as a world community. ${ }^{16}$

In Axis Rule in Occupied Europe, then, Lemkin sees genocide as multifaceted. It can be constituted in a destructive act or episode or event. It can also encompass longer-term processes such as settler colonialism that can include destructive acts or episodes or events. A key passage on the opening page of chapter nine tells us:

Genocide has two phases: one, destruction of the national pattern of the oppressed group; the other, the imposition of the national pattern of the oppressor. This imposition, in turn, may be made upon the oppressed population which is allowed to remain, or upon the territory alone, after removal of the population and the colonization of the area by the oppressor's own nationals. ${ }^{17}$

Very importantly, Lemkin here defines genocide as a twofold process of destruction and replacement - a process that entwines genocide and colonisation. ${ }^{18}$

In the postwar years, Lemkin worked tirelessly in the circles of the fledgling United Nations to persuade relevant committees to pass a convention banning genocide. ${ }^{19}$ At the same time, from 1947, he was writing a history describing many examples of genocide in history, which he could submit as memoranda to influential delegates. ${ }^{20}$ Lemkin's book on the history of genocide remained unfinished and unpublished when he died in 1959. Yet the various manuscript chapters and research notes and cards make fascinating reading. In particular, Lemkin pursued the linking of colonisation with genocide made in chapter nine of Axis Rulein Occupied Europe to include European colonisation around the world, including of the Americas by the Spanish from 1492 and later in North America by the English, French and post-independence Americans. He also

\footnotetext{
16 Lemkin, Axis Rule in Occupied Europe, ch. IX, pp. 79-95. For an extended evocation of chapter nine, see Curthoys and Docker, 'Introduction-genocide', pp. 5-11.

17 Lemkin, Axis Rule in Occupied Europe, pp. xi, 79-80.

18 Tony Barta, in his pioneering essays of the 1980s, recognised the importance of Lemkin's linking in chapter nine of genocide with colonisation as a twofold process: Barta, Tony 1984, 'After the Holocaust: consciousness of genocide in Australia', Australian Journal of Politics and History, vol. 31, no. 1; Barta, Tony 1987, 'Relations of genocide: land and lives in the colonization of Australia', in Isidor Wallimann and Michael N. Dobkowski (eds), Genocide and the Modern Age: Etiology and case studies of mass death, Greenwood Press, New York.

19 The story is told in some detail in Power, Samantha 2002, 'A Problem from Hell': America and the age of genocide, HarperCollins Perennial, New York; and in Weiss-Wendt, Anton 2005, 'Hostage of politics: Raphaël Lemkin on "Soviet genocide"', Journal of Genocide Research, vol. 7, no. 4, pp. 551-9.
}

20 Power, 'A Problem from Hell', p. 54 ff. 
included Australia within his linking of colonisation and genocide, and Ann Curthoys and I were fortunate to discover in his papers a remarkable essay on Tasmania as an example of genocide..$^{21}$

Among Lemkin's papers is also a diagram, 'Revised outline for genocide cases', in which he lists detailed methodological categories by which to analyse historical genocides, though I think these categories can be deployed as well to analyse literary and cultural texts that in my view are concerned with genocide, such as Euripides' Hecabe or Shakespeare's The Tempest; such in any case I have attempted in my book The Origins of Violence: Religion, history and genocide (2008). In 'Revised outline for genocide cases', Lemkin suggests that the history of genocide could be explored in terms of categories such as historical background; methods and techniques of genocide-physical, biological and cultural; the attitudes of the genocidists; propaganda - that is to say, rationalisation of the crime; responses of victim groups - active and passive; responses of outside groups; and aftermath, which includes 'moral deterioration' ${ }^{22}$

In my The Origins of Violence, I regard Odysseus in Hecabe and Prospero in The Tempest as genocidists whose actions and speeches reveal 'moral deterioration' Lemkin's term here resonating with Hannah Arendt's notions in The Origins of Totalitarianism of the general ethical deterioration in those who conquer. In Hecabe, Troy having been conquered and its men and warriors massacred, including Priam, Queen Hecabe's husband, the Greeks demand further sacrifices of the Trojans. The ghost of Achilles asks that a young woman be sacrificed over his grave and Hecabe's daughter Polyxena is chosen, Odysseus insisting on her death by having her throat cut - in full view of the Greek army. Odysseus takes it on himself to go to Hecabe and tell her that he has come to take Polyxena to Achilles' tomb where she will be slain by Achilles' son. Hecabe, already traumatised by so much suffering in her family, attempts to appeal to Odysseus's compassion and humanity, but finds only mercilessness and indifference. Lemkin's term 'moral deterioration', and the chilling portrait of Odysseus in Hecabe, might remind us of Arendt's description of Adolf Eichmann as an impersonal functionary, banally efficient in his genocidal consciousness. ${ }^{23}$

In The Tempest - famous for its exploration of questions of colonisationProspero, the usurped Duke of Milan, and his daughter, Miranda, arrive at an island whose sole occupant is Caliban, who regards himself as its rightful owner. Prospero as coloniser immediately assumes possession and rights of settlement. Caliban passionately protests - in a great speech that has something

21 Curthoys, Ann 2005, 'Raphael Lemkin's “Tasmania": an introduction', and Lemkin, R. 'Tasmania', in Ann Curthoys (ed.), Patterns of Prejudice, vol. 39, no. 2, pp. 162-96, reprinted in Moses, A. Dirk and Stone, Dan (eds) 2007, Colonialism and Genocide, Routledge, London, pp. 66-100.

22 Docker, The Origins of Violence, pp. 3, 62-4.

23 Ibid., pp. 69-73. 
of the tragic grandeur of Shylock's anger at his belittlement and humiliation in The Merchant of Venice. Caliban points out that Prospero has dispossessed him of his world, his way of life that he enjoys and that he feels constitutes his distinctive existence, and that he had inherited from his mother. In terms of Lemkin's definition of genocide in Axis Rule in Occupied Europe- of genocide as destruction of the foundations of life of an oppressed group, subjugation of its local population and replacement by the new pattern of the oppressorProspero destroys Caliban's world and replaces it with his own, reducing the once proud and independent Caliban to slavery. Caliban experiences what Lemkin refers to as demoralisation in the victim of genocide, descending from a near-tragic figure revealed in his great speech of protest to a minor fool, cowed by Prospero into terror and drunkenness. We also observe Prospero's ethical deterioration as a genocidist coloniser: his resort to a language of insult with not only Caliban but his other slave, Ariel; his querulousness and authoritarianism, even with Miranda; and his use of torture and the pleasure he takes in cruelty in inflicting various kinds of punishment and pain on Caliban in his attempts to completely subjugate him. ${ }^{24}$

In the unfinished manuscript, Lemkin develops a sophisticated methodology - as in 'Revised outline for genocide cases' - that permits the possibility of intricate and subtle analyses of settler-colonial histories in relation to genocide. Lemkin is highly critical of Christopher Columbus as an egregious genocidist who set the historical example for the future of Spanish colonisation in the Americas, instituting slavery and catastrophic loss of life. He carefully distinguishes between cultural change and cultural genocide. He points out that the relationship between oppressor and victim in history is always unstable, and that in world history there are many examples of genocidal victims transforming into genocidists - the formerly persecuted into the persecutors of others. He points to recurring features in historical genocides: mass mutilations; deportations under harsh conditions often involving forced marches; attacks on family life, with separation of men and women and the taking away of the opportunity for procreation; removal and transfer of children; destruction of political leadership; death from illness, hunger and disease through overcrowding on reserves and in concentration camps. ${ }^{25}$

Lemkin's views on humanity and violence were double-edged-both pessimistic and optimistic. The concept of genocide has led to the sombre re-conceptualisation of the whole of human history as involving a history of

\footnotetext{
24 Ibid., pp. 181-6.

25 See Docker, John 'Are settler-colonies inherently genocidal? Re-reading Lemkin', in Moses, Empire, Colony, Genocide, pp. 81-101. See also Docker, John 2004, Raphael Lemkin's history of genocide and colonialism, Paper for US Holocaust Memorial Museum, Center for Advanced Holocaust Studies, Washington, DC, 26 February 2004.
} 
genocide - that it occurs in relations between groups with a certain regularity just as homicide takes place between individuals. Yet Lemkin fervently hoped and believed that international law could restrain or prevent genocide.

In retrospect, we can see Lemkin's historical conceptions and legal thinking emerging from a 1930s and 1940s context in which émigré and exiled intellectuals were attempting to reprise and develop traditions of cosmopolitanism and internationalism that they saw being engulfed by Nazism - itself a culmination of nineteenth-century nationalism and colonialism. Figures such as Walter Benjamin, Sigmund Freud, Lemkin, Hannah Arendt, Erich Auerbach, Albert Einstein and Leo Spitzer were concerned that humanity should establish a duty of care to all the world's peoples and cultures. ${ }^{26}$

We can see Lemkin's undeniable eccentricity in terms of Isaac Deutscher's portrait of the non-Jewish Jew as an intellectual figure whose distinctiveness whose pathos and advantage - is to be between cultures, societies, civilisations. ${ }^{27}$ Here, Lemkin's heritage could perhaps include the most famous of non-Jewish Jews: Spinoza, in the early Enlightenment, who himself reprises the figure of the Marrano so prominent in the history of the Spanish Sephardic diaspora in Portugal and Holland in the sixteenth and seventeenth centuries - a cultural figure whose inner consciousness was multi-contradictory, confused, dissonant, ambivalent, paradoxical, incomplete, doubting, self-doubting and potentially or actually heretical. ${ }^{28}$ We can speculatively expand on this genealogy: Spinoza, with his Sephardic family ancestry, and in his inventiveness and creativity as a philosopher, builds on the intellectual brilliance of medieval Moorish Spain, al-Andalus or Andalusia - a society of convivencia between Muslims, Jews and Christians, for eight centuries a multi-religious and multi-ethnic part of Europe itself. As Maria Rosa Menocal in The Ornament of the World (2002) evokes it, Moorish Spain created a vibrant culture that profoundly influenced - and continues to influence - European and world history in terms of poetry, narrative, science, astronomy, mathematics, medicine, historiography, translation, religion, mysticism, architecture and philosophy. ${ }^{29}$

Beyond such particular features of al-Andalus there was, Menocal suggests, a kind of general Andalusian sensibility that was positive, productive and

26 Cf. Clark, Katerina 2002, 'M. M. Bakhtin and "world literature"', JNT: Journal of narrative theory, vol. 32, no. 3, pp. 266-92; and Curthoys, Ned 2005, 'The émigré sensibility of world literature: historicizing Hannah Arendt and Karl Jaspers' cosmopolitan intent', Theory and Event, vol. 8, no. 3. Apropos Einstein, see Jerome, Fred 2002, The Einstein File: J. Edgar Hoover's secret war against the world's most famous scientist, St Martin's Press, New York.

27 Deutscher, Isaac 1968, The Non-Jewish Jew, Oxford University Press, London.

28 Cf. Docker, John 2001, 1492: The poetics of diaspora, Continuum, London, pp. 88, 99-102; Yovel, Yirmiyahu 1989, The Marrano of Reason, Princeton University Press, NJ, pp. 19-22, 28, 41, 65, 83-4, 98.

29 Menocal, Maria Rosa 2002, The Ornament of the World: How Muslims, Jews, and Christians created a culture of tolerance in medieval Spain, Little, Brown and Co., New York, pp. 5-9, 27-30, 34, 59-61, 64, 75, 78, 205-6. See also Curthoys and Docker, 'Is a history of humanity possible?', pp. 251-3. 
influential in European and world history - a capacity of living with possible irreconcilability and incongruity: 'In the end, much of Europe far beyond the Andalusian world, and far beyond modern Spain's geographical borders, was shaped by the deep-seated vision of complex and contradictory identities that was first elevated to an art form by the Andalusians. ${ }^{30}$ Menocal writes in The Ornament of the World that nineteenth-century German Jews 'saw in those urbane, philosophically mature, and socially successful Jews of the eleventh and twelfth centuries a winning reflection of what they wished the European Jews of the nineteenth [century] to be'. ${ }^{31}$

Menocal's observation here resonates with Ned Curthoys' argument, in his 2010 essay 'Diasporic visions: al-Andalus in the German-Jewish imaginary', that there was a powerful affinity between Jewish cultural achievement in medieval Moorish Spain and a pluralist, diasporic vision of Jewish identity articulated by German-Jewish intellectuals in modernity. Such affinity is evident in a lineage extending from the philosopher Moses Mendelssohn in the eighteenth-century German Enlightenment through to writers, historians and theologians such as Heinrich Graetz, Abraham Geiger and Heinrich Heine in the nineteenth century. German-Jewish intellectuals, Curthoys reflects, feeling themselves estranged from normative identities, positioned themselves at the borders of different cultures; they often identified as well with the 'cultured rationalism and resilient intellectual independence' of Spinoza. Curthoys concludes by suggesting that the Andalusian ethos and heritage influenced twentieth-century critics such as Edward Said, Spitzer and Auerbach, the great Palestinian poet Mahmoud Darwish and, most recently, the American-Jewish philosopher Judith Butler. ${ }^{32}$

In these terms, there is, I suggest, an affinity between the ever-persisting stream of many-centuries-long 'Andalusian' intellectual life and sensibility and the resilience, independence and idiosyncrasy of Raphaël Lemkin. Central to Lemkin's thought were notions of world culture and the oneness of the worldvaluing the variety and diversity of human cultures. ${ }^{33}$

\footnotetext{
30 Menocal, The Ornament of the World, p. 12.

31 Ibid., p. 161.

32 Curthoys, Ned 2010, 'Diasporic visions: al-Andalus in the German-Jewish imaginary', in Christopher Wise and Paul James (eds), Being Arab: Arabism and the politics of recognition, Arena Publications, Melbourne, pp. 110-38. In an interview ('Judith Butler: as a Jew, I was taught it was ethically imperative to speak up', Haaretz, 24 February 2010), Butler tells an amusing anecdote of a conversation when she was just fourteen with her rabbi, who was taken aback by her independent spirit. Butler asked the rabbi 'why Spinoza was excommunicated from the synagogue. I wanted to know what happened and whether the synagogue was justified.'

33 Lemkin, Axis Rule in Occupied Europe, pp. 91 and 91n.51; 'Totally unofficial man', p. 377; 'Genocide-a modern crime', Free World:A magazine devoted to the United Nations and democracy, April 1945, pp. 39-43, $<$ http://www.preventgenocide.org/lemkin/freeworld1945.htm>
} 


\section{The UN Convention on Genocide, 1948}

Lemkin in effect produced, or influenced into being, two definitions of genocide: the discursive definition in chapter nine of Axis Rule in Occupied Europe and the codified definition of the 1948 UN Genocide Convention. A tortuous political process in a divided Cold War atmosphere meant that what emerged was a narrower definition than the one Lemkin originally proposed, omitting political and cultural genocide. ${ }^{34}$

The Articles of the UN Convention on the Prevention and Punishment of the Crime of Genocide (United Nations General Assembly, 9 December 1948) became widely known and quoted. ${ }^{35}$ Article II sets out the key clauses of the definition:

In the present Convention, genocide means any of the following acts committed with intent to destroy, in whole or in part, a national, ethnical, racial or religious group, as such:

- Killing members of the group;

- Causing serious bodily or mental harm to members of the group;

- Deliberately inflicting on the group conditions of life calculated to bring about its physical destruction in whole or in part;

- Imposing measures intended to prevent births within the group;

- Forcibly transferring children of the group to another group.

The omission of political and cultural genocide was a cause for regret in some quarters, and has remained an issue in scholarly and legal debate ever since. Lemkin especially regretted the exclusion of cultural genocide ('very dear to me'). In 'Totally unofficial man', Lemkin explains that he could not persuade the relevant UN committee meeting in Paris after World War II to include an article in the final convention on 'cultural genocide':

I defended it successfully through two drafts. It meant the destruction of the cultural pattern of a group, such as the language, the traditions, the monuments, archives, libraries, churches. In brief: the shrines of the soul of a nation. But there was not enough support for this idea in the Committee... So with a heavy heart I decided not to press for it. ${ }^{36}$

The case of cultural genocide is especially complex. The genocide historian Leo Kuper reflects that while cultural genocide was dropped from the convention

34 See Kuper, Leo 1981, Genocide: Its political use in the twentieth century, Yale University Press, New Haven, Conn., ch. 2, pp. 19-39.

35 See, for example, Power, 'A Problem from Hell', pp. 62-3; also <http://www.preventgenocide.org/law/ convention/text.htm>

36 Lemkin, 'Totally unofficial man', p. 393. 
it survived in vestigial form in the prohibition on the forcible transfer of children from one group to another, and in the term 'ethnical' group, suggesting protection of groups with distinctive culture or language. ${ }^{37} \mathrm{Ann}$ Curthoys and I also argue that the notion of 'mental harm' was and is open to being interpreted as implying cultural as well as psychological genocide. ${ }^{38}$

We must also remember that in Lemkin's 1944 definition in Axis Rule in Occupied Europe the cultural and political were both strongly present as part of the manifold ways the essential foundations of life of a group were being destroyed. ${ }^{39}$ Lemkin's 1944 definition and the Lemkin-influenced definition enshrined in the 1948 convention have acted in subsequent thinking about genocide like a double helix - neither reducible one to the other nor wholly separable. The definition of genocide, that is, always has a double character: both discursive and legal. In my view, we should not base the historical study of genocide on a legal definition alone; indeed, we should not base the historical study of any phenomena on a legal definition alone.

\section{Disturbing aspects}

Let us return to Lemkin's biographical journey, this time questioning aspects of his thinking and attitudes in relation to African Americans, Africa and Africans. ${ }^{40}$

Genocide as a concept and UN legal convention proved almost immediately to be troubling and problematic in the context of the Cold War. In the United States in the early 1950s, two groups in particular competed to have the United Nations consider accusations of genocide: Eastern European émigrés wanted charges of Soviet genocide while radical African Americans sought charges of American genocide. As a public figure, Lemkin - the, as it were, father of the Genocide Convention-became involved in these disputes, though regrettably not on the side of the African-American intervention.

The disputes reached a peak in December 1951, when a petition entitled We Charge Genocide was presented by Paul Robeson and others to the UN Secretariat

37 Kuper, Genocide, p. 31. Cf. Moses, A. Dirk, 'Genocide and settler society in Australian history', in Moses, A. Dirk (ed.) 2004, Genocide and Settler Society: Frontier violence and stolen Indigenous children in Australian history, Berghahn, New York and Oxford, pp. 22-3, and his chapter 'The Holocaust and genocide' in Stone, Dan (ed.) 2004, The Historiography of the Holocaust, Palgrave, London, p. 542.

38 Curthoys and Docker, 'Defining genocide', p. 14.

39 Cf. Kuper, Genocide, p. 30; Curthoys and Docker, 'Introduction-genocide', p. 10.

40 An earlier version of this section of my argument is in Curthoys and Docker, 'Defining genocide', pp. $15-21$. 
in New York. ${ }^{41}$ At the same time, William L. Patterson, the petition's main author, presented it to the UN General Assembly in Paris. ${ }^{42}$ In Black and Red: W. E. B. Du Bois and the Afro-American response to the Cold War 1944-1963 (1986), Gerald Horne writes that Patterson would have liked Du Bois to fly to Paris to present the petition, but Du Bois' doctors advised against it; on 19 February 1951, Du Bois had been indicted as an 'unregistered foreign agent' and was handcuffed before appearing in court; he would subsequently be acquitted. ${ }^{43}$ We Charge Genocide was not the first African-American attempt to seek redress through the United Nations. In 1947, Du Bois, in a statement entitled 'Appeal to the world', had petitioned it on behalf of the National Association for the Advancement of Colored People (NAACP). The 1951 We Charge Genocide petition, however, was the first attempt to charge the United States with genocide under the UN Convention. ${ }^{44}$ In brief, it argued that the lynching and other forms of assault on the lives and livelihoods of African Americans from 1945 to 1951, especially the frenzied attacks on returning black American veterans, amounted to genocide. ${ }^{45}$

The originator of the petition was the Civil Rights Congress (CRC), a vigorous, fearless and always controversial communist-led organisation that fought for African-American rights. ${ }^{46}$ Patterson was national secretary of the CRC from 1946 to 1956; he was also a lawyer and a member of the Communist Party. ${ }^{47}$ The American Communist Party was itself a party with large African-American membership and support. In an essay concerning a visit by Du Bois to Warsaw, Michael Rothberg comments: 'During this era...Communism provided a discursive space in the United States in which the articulation of genocide and colonialism could first be attempted - and this long before the intellectual vogue for either Holocaust or postcolonial studies. ${ }^{\prime 48}$

In her scintillating memoir, A Fine Old Conflict (1977), Jessica Mitford writes that when she moved to Oakland, California, in 1947, she became assistant to 'Hursel Alexander, a black organizer who was executive director of the East Bay

41 Cf. Curthoys, Ann 2010, 'Paul Robeson's visit to Australia and Aboriginal activism, 1960', in Frances Peters-Little, Ann Curthoys and John Docker (eds), Passionate Histories: Myth, memory and Indigenous Australia, ANU E Press, Canberra.

42 Patterson, William L. 1971, The Man Who Cried Genocide: An autobiography, International Publishers, New York, p. 184.

43 Horne, Gerald 1986 Black and Red: W. E. B. Du Bois and the Afro-American response to the Cold War 1944-1963, State University of New York Press, Albany, pp. 151, 178, 181.

44 Patterson, The Man Who Cried Genocide, pp. 10-11, 171-7, 180, 183-4, $185 \mathrm{ff}$. The We Charge Genocide petition (p. 143) refers to 'Appeal to the world', prepared by Du Bois for the NAACP in 1947.

45 Civil Rights Congress 1951, We Charge Genocide: The historic petition to the United Nations for relief from a crime of the United States Government against the Negro people, Civil Rights Congress, New York, p. 8.

46 Horne, Gerald 1988, Communist Front? The Civil Rights Congress, 1946-1956, Associated University Presses, London and Toronto, pp. 13-21, 48, 69.

47 See Patterson, The Man Who Cried Genocide, pp. 9-10.

48 Rothberg, Michael 2001, 'W. E. B. Du Bois in Warsaw: Holocaust memory and the color line, 1949-1952', The Yale Journal of Criticism, vol. 14, no. 1, p. 174. See also Gilmore, Glenda Elizabeth 2009, Defying Dixie: The radical roots of civil rights, 1919-1950, W. W. Norton, New York. 
Civil Rights Congress', then a 'dynamic, predominantly black organization with some five hundred active dues-paying members'; she later became its executive secretary. Patterson, she reports, often came from New York to meet with CRC chapters around the country and she describes him as a 'formidable figure'. ${ }^{49}$

The CRC focused its campaigns on cases of racist oppression, and as well as Jessica Mitford (her married name was Decca Treuhaft), who became its East Bay leader in California, it attracted the support of well-known people such as Dashiell Hammett, who went to jail as a result of being a trustee of the CRC's Bail Fund, and African-American entertainers such as Robeson, Josephine Baker and Lena Horne. In addition to skilled legal challenges, it engaged in picketing, demonstrations and petitioning - for example, in the cases of Willie McGee, Rosa Lee Ingram, the Trenton Six and the Martinsville Seven. ${ }^{50}$ In $A$ Fine Old Conflict and in letters of this time, Mitford evokes her 1951 visit to Mississippi prompted by the Willie McGee case, which was also protested by Albert Einstein and Josephine Baker. ${ }^{51}$ The CRC strongly believed that a focus on Jim Crow laws and deprivation of blacks' rights would be an embarrassment for the United States abroad and might hasten overdue reform, and in this it was prophetic; such tactics were successfully adopted by the American civil rights movement a decade later. ${ }^{52}$

We Charge Genocide is a remarkable document, very powerfully argued. The opening title pages reprinted Articles II and III of the 1948 Genocide Convention. ${ }^{53}$ The list of names of the petitioners included Du Bois, Robeson, Mitford and Ben Davis. ${ }^{54}$ In his introduction, Patterson noted that it was 'sometimes incorrectly thought that genocide means the complete and definitive destruction of a race or people'. He pointed out that the Genocide Convention defined genocide as 'killing members of the group', and that genocide was any intent to destroy, in whole or in part - this phrase Patterson italicised - a national, racial, ethnic or religious group. Thus, as well as 'killing members of the group', genocide is constituted in 'causing serious bodily or mental harm'. The petition would

\footnotetext{
49 Mitford, Jessica 1977, A Fine Old Conflict, Alfred A. Knopf, New York, pp. 104-7, 118, 127.

50 Horne, Communist Front?, pp. 13-21, 48, 69.

51 Mitford, A Fine Old Conflict, ch. 8, pp. 160-94. See also Mitford's letters to her mother, Lady Redesdale, dated 2 April 1951 and 23 September 1951, in Sussman, Peter Y. (ed.) 2006, Decca: The letters of Jessica Mitford, Weidenfeld and Nicholson, London, pp. 139-42.

52 Cf. Dudziak, Mary L. 2000, Cold War Civil Rights: Race and the image of American democracy, Princeton University Press, NJ; and Von Eschen, Penny M. 1997, Race Against Empire: Black Americans and anticolonialism 1937-1957, Cornell University Press, Ithaca and London.

53 In The Man Who Cried Genocide (p. 179), Patterson provides brief biographical information for some of these co-authors: 'Richard Boyer, historian and author; Elizabeth Lawson, biographer and pamphleteer; Yvonne Gregory, writer and poet; and Dr Oakley Johnson, scholar in British and American literature.'

54 Cf. Patterson, The Man Who Cried Genocide, p. 180. Apropos Davis, see Horne, Gerald 1994, Black Liberation/Red Scare: Ben Davis and the Communist Party, University of Delaware Press, Newark, NJ, pp. 9, 13.
} 
maintain, Patterson said, that the 'oppressed Negro citizens of the United States' suffer from genocide as the result of the 'consistent, conscious, unified policies of every branch of government'. ${ }^{55}$

The petition called on the United Nations to 'act and to call the Government of the United States to account' ${ }^{56}$ Genocide, it contended, could not be sequestered as an internal affair of the United States, but was a problem for the world. ${ }^{57}$ The world had fought the crimes of Nazism 'against the heroic Jewish people'; every word voiced by US Supreme Court Judge Robert H. Jackson in his opening address to the Nuremberg trial of the Nazi leaders 'applies with equal weight' to racist perpetrators in the United States. ${ }^{58}$ The petition urged the world to consider the urgency of its request in terms of the US threat to world peace, because Hitler had already demonstrated that 'domestic genocide develops into the larger genocide that is predatory war' ${ }^{59}$ Already, it observed with 'peculiar horror', the 'genocidal doctrines and actions of the American white supremacists' against the African-American people-looting and burning of homes, killing of children, raping of women - are being exported to the 'colored people of Asia'. ${ }^{60}$ Here, We Charge Genocide anticipates Sartre's similar suggestion in On Genocide (1967), his famous report to Bertrand Russell's International War Crimes Tribunal, in which he judges that the American war in Vietnam was genocidal and that the brutality and cruelty practised by American soldiers had deep historical roots in the United States, as in the anti-black racism of Southern whites. $^{61}$

In reference to the 15 million black people of the United States, the petition indicts the US State at every level, arguing, for example, that 'more than 10,000 Negroes' have been killed. They are killed by the Ku Klux Klan - 'that organization which is chartered by...several states as a semi-official arm of government and even granted the tax exemptions of a benevolent society'. Frequently, they have been framed and murdered by sham legal processes and a supportive legal bureaucracy. They are killed by police not only in the South but in every city in the United States: 'in the back rooms of sheriff's offices, in the cells of county jails, in precinct police stations and on city streets.' When the bodies of murdered African Americans are found, they have often been 'horribly

\footnotetext{
55 Civil Rights Congress, We Charge Genocide, pp. xi-xiii, also 32.

56 Ibid., pp. xii-xiii, also 31, 35-6.

57 Ibid., p. xii.

58 Concerning the postwar use of the term 'holocaust' by the Communist Party and those close to it in referring to the Nazi genocide of the Jews, cf. Novick, Peter 2000 [1999], The Holocaust in American Life, Houghton Mifflin, New York, pp. 93-4.

59 Civil Rights Congress, We Charge Genocide, p. 31.

60 Ibid., pp. 3, 7, also 57.

61 Sartre, J.-P. 1968, On Genocide, and a Summary of the Evidence and the Judgments of the International War Crimes Tribunal, A. El Kaim-Sartre (ed.), Beacon Press, Boston, pp. 78-82; Curthoys and Docker, 'Defining genocide', p. 25.
} 
mutilated'. African Americans, the petition continues, live in a state of terror of being lynched or shot, which contravenes that part of the Genocide Convention forbidding the causing of serious mental harm to members of a group. ${ }^{62}$

The petition quotes the convention on genocide as 'deliberately inflicting on the group conditions of life calculated to bring about its destruction in whole or in part' and draws attention to the existence and effects of such conditions in the United States. ${ }^{63}$ 'From birth to death,' it says:

Negro Americans are humiliated and persecuted, in violation of the Charter and the Convention. They are forced by threat of violence and imprisonment into inferior, segregated accommodations, into jim crow busses, jim crow trains, jim crow hospitals, jim crow schools, jim crow theaters, jim crow restaurants, jim crow housing, and finally into jim crow cemeteries. ${ }^{64}$

In violation of the convention, there is a mass of segregationist American law 'written as was Hitler's law': solely on the basis of 'race'. In many American states, it was a crime for a 'white person to marry a Negro'. There was no true democracy in the United States, because in 'huge and decisive areas' where African-Americans were the preponderant population, they were prevented from voting by 'terror' supported not only by governors, senators, judges and peace officers, but also by the Government of the United States, its Congress and its executive branch. The Supreme Court refused to intervene in blatantly framed cases leading to electrocution, and in general the Supreme Court has 'delivered a people-Americans it was supposed to protect - to degradation and violence'. The government, either by executive or judicial action, had done nothing to void the many 'racist anti-Negro laws of the several states', though it clearly had the power to do so. ${ }^{65}$ The petitioners, recalling Shylock's anguished cry in The Merchant of Venice and Caliban in The Tempest, protested 'this genocide as human beings whose very humanity is denied and mocked'. 'We cannot believe,' they concluded, 'that the General Assembly will not condemn the crimes complained of in this petition. ${ }^{66}$

The General Assembly did not adopt the petition. Given the limitations of UN power and responsibility at this time and the Cold War context, there was no way it could succeed in producing a UN indictment of the United States. Nevertheless, Patterson thought that the action itself of presenting the petition to the United Nations was a signal symbolic success in drawing attention to the situation of African Americans in the postwar world: 'An ideological and moral

62 Civil Rights Congress, We Charge Genocide, pp. 3-4, 6, 8-9, 19, 144.

63 Ibid., p. 5.

64 Ibid., p. 5.

65 Ibid., pp. 6-9, 36, 57, 178-9, 182-3. Cf. Jerome, The Einstein File, pp. 72, 74.

66 Civil Rights Congress, We Charge Genocide, pp. 7-8, 195-6. Concerning Caliban, see the analysis of The Tempest in Docker, The Origins of Violence, pp. 182-6. 
victory had already been won, the moral bankruptcy of US leaders even in the UN had been exposed.' He also reported that his visit to Paris had 'received a good European press' and that a total of 45000 copies of the petition were sold in the United States. ${ }^{67}$

\section{African Americans, Africa, Africans: Lemkin's hostility to We Charge Genocide}

Within the United States, the reception of the We Charge Genocide petition was marked by two main features: race and the Cold War. ${ }^{68}$ The racial divide was generally clear: while many African Americans supported the petition, most American whites did not. The Cold War divide was even clearer: proSoviet commentators were in favour of the petition and anti-Soviet opinion against. Without exception, law academics were adamantly opposed because any attempt to apply the Genocide Convention to the US situation would in their view affect the integrity of 'our nation' ${ }^{69}$ One of these legal academics was Lemkin himself, who, Patterson later wrote, 'argued vehemently that the provisions of the Genocide Convention bore no relation to the US Government or its position vis-à-vis Black citizens'. When The New York Times on 18 December 1951 asked Lemkin what he thought, he replied that the accusations were a manoeuvre to 'divert attention from the crimes of genocide committed against Estonians, Latvians, Lithuanians, Poles and other Soviet-subjugated peoples'. Patterson and Robeson, he declared, were 'un-American' elements, serving a foreign power. ${ }^{70}$ Later, on 14 June 1953, Lemkin wrote an op-ed piece for The New York Times in which he declared that African Americans enjoyed conditions of increasing prosperity and progress in the United States; though they might experience discrimination, they had not suffered 'destruction, death, annihilation' - the essence of genocide - an odd narrowing of both his own original definition and that of the UN Convention. In response to The New York Times op-ed, Oakley Johnson, one of those who helped write We Charge Genocide, wrote to Lemkin protesting that scare tactics and discrimination were not a case of white Americans frightening individual black Americans but of creating anguish in a racial group as a group; it concerned the terrorising of a whole race of people. ${ }^{71}$

\footnotetext{
67 Patterson, The Man Who Cried Genocide, pp. 197, 199, 207, 212; Horne, Communist Front?, p. 169.

68 See Rabinbach, Anson 2005, 'The challenge of the unprecedented-Raphael Lemkin and the concept of genocide', Simon Dubnow Institute Yearbook 4, pp. 401, 411-16.

69 Cf. Elder, Tanya 2005 'What you see before your eyes: documenting Raphael Lemkin's life by exploring his archival papers, 1900-1959', Journal of Genocide Research, vol. 7, no. 4, p. 470, concerning the strong opposition by the American Bar Association to treaties including the UN Convention.

70 Patterson, The Man Who Cried Genocide, pp. 179, 191.

71 Elder, 'What you see before your eyes', pp. 486-7.
} 
Why was Lemkin so opposed to the We Charge Genocide petition? Samantha Power observes that Lemkin intensely felt that concerns about discrimination and prejudice were the province of the United Nations' Universal Declaration of Human Rights, which was passed by the General Assembly on 10 December 1948 - a day after the Genocide Convention. In Lemkin's irritated view, the Universal Declaration of Human Rights dealt with individual problems, not with the group rights of peoples as demanded by the concept of genocide; for Lemkin, it represented a diversion from the Genocide Convention, with the added danger that the two conventions would be confused in the public mind. ${ }^{72}$ Anson Rabinbach suggests that Lemkin, dismissing We Charge Genocide as concerned with discrimination not destruction, was also concerned that charges of racial genocide within the United States might mean the final blow to American ratification of the Genocide Convention. ${ }^{73}$ Yet We Charge Genocide had made it very clear - in careful and detailed ways addressing the specific terms of Article II of the convention - that it was throughout speaking to AfricanAmerican group experience.

Deeply unsettling questions remain concerning Lemkin and his attitudes to African-American history and people; perhaps there was a fundamental lack of sympathy. It might be fruitful to compare Lemkin in this regard with Einstein, who actively supported the struggle for African-American human rights and enjoyed longstanding friendships with intellectuals and cultural figures such as Robeson, Du Bois and Marian Anderson. In The Einstein File: J. Edgar Hoover's secret war against the world's most famous scientist (2002), Fred Jerome relates an incident of 16 April 1937 involving the African-American singer Anderson. After the great diva had given a concert to a standing-room-only audience at Princeton's McCarter Theatre, she was nonetheless refused a room in Princeton's Nassau Inn; Einstein immediately invited her to stay at his home and their ensuing friendship would last for the rest of his life. Jerome also writes that, on Robeson's invitation, Einstein in September 1946 became co-chairman of a group that Robeson was establishing: the American Crusade to End Lynching. ${ }^{74}$

Dominik J. Schaller, analysing Lemkin's unpublished manuscripts, expresses dismay at Lemkin's views on European colonial rule in Africa, commenting that Lemkin swayed between condemnation and admiration. In terms of the German colonial war against the Herero in Namibia, Schaller feels that there can be no doubt that Lemkin 'regarded his concept of genocide' as 'perfectly applicable to the events of 1904-1908'. Yet Lemkin also, he points out, fell in with a myth that the Herero, unable to reconcile themselves to subjection and loss of independence, chose to kill themselves in a kind of national suicide, with

72 Power, 'A Problem from Hell', pp. 74-5.

73 Rabinbach, 'The challenge of the unprecedented', pp. 413-14.

74 Jerome, The Einstein File, pp. 76-8, 82, 85, 126, 132-3. 
particular blame being attached to the Herero women. Lemkin considered that the imposition of Belgian colonial rule in the Congo, and the forced labour of the indigenous population that accompanied it, was genocide, yet described the 'native militia' in the pay of the Belgians as 'savages' and 'cannibals'. Schaller says that Lemkin has to be recognised as an 'enthusiastic advocate of colonialism' by European powers in Africa, seeing it as a necessary task that Europeans bring 'civilisation' to the continent. The ways Lemkin perceived Africans, Schaller concludes, 'can only be described as racist': 'Africans are portrayed as either weak-willed and helpless victims or as bloodthirsty cannibals. ${ }^{.75}$

\section{Arendt and Black Power}

Perhaps Lemkin can be compared here with Hannah Arendt, whose attitudes to African Americans and Africa are proving increasingly controversial. ${ }^{76}$ We can focus on her 1969 book, On Violence, which has been devastatingly critiqued by Anne Norton, who highlights egregious sentences and passages on which I also will be commenting. ${ }^{77}$ On Violence is certainly insightful in its focus on the 'all-pervading unpredictability' of violence. ${ }^{78}$ Yet jostling in its text, footnotes and endnotes are claims and assertions that make uncomfortable reading. In $O n$ Violence, Arendt is responding to a general move in the New Left during the 1960s away from the Gandhian philosophy of non-violence that inspired Martin Luther King jr and the civil rights movement in the United States - and, we can add, the anti-nuclear campaigns in Britain. ${ }^{79}$

Arendt writes that the New Left generation seems everywhere characterised by 'sheer courage, an astounding will to action, and by a no less astounding

75 Schaller, Dominik J. 2005, ‘Raphael Lemkin's view of European colonial rule in Africa: between condemnation and admiration', Journal of Genocide Research, vol. 7, no. 4, pp. 531-8. See also Schaller, 'From conquest to genocide: colonial rule in German Southwest Africa and German East Africa', in Moses, Empire, Colony, Genocide, pp. 296-324; Jürgen Zimmerer, 'Colonial genocide: the Herero and Nama war (1904-8) in German South West Africa and its significance', in Stone, The Historiography of Genocide, pp. 323-43.

76 See King, Richard H. and Stone, Dan (eds) 2007, Hannah Arendt and the Uses of History: Imperialism, nation, race, and genocide, Berghahn, New York, pp. 10-11, 14.

77 See Norton, Anne 1995, 'Heart of darkness: Africa and African Americans in the writings of Hannah Arendt', in Bonnie Honig (ed.), Feminist Interpretations of Hannah Arendt, Pennsylvania State University Press, University Park, pp. 247-61.

78 Arendt, Hannah 1970 [1969], On Violence, Harcourt Brace Jovanovich, New York, p. 5.

79 Ibid., pp. 3, 11, 13-14. Sean Scalmer (in his essay 'Gobalising Gandhi: translation, reinvention, application, transformation', in Debjani Gandguly and John Docker [eds], Rethinking Gandhi and Nonviolent Relationality: Global perspectives, Routledge, London, p. 152) writes that the 'history of the Western Left in the 1960s is largely the story of the abandonment of nonviolence for more "radical", "revolutionary", and violent poses...Ho Chi Minh was preferred to Gandhi. Soon, Satyagraha seemed a creature of the past.' The move away from non-violence could, however, be difficult to date exactly, and might not in any case have been comprehensive. The 1965 Australian Freedom Ride was inspired by a philosophy of non-violence that drew on Martin Luther King jr's Gandhian inheritance. See Curthoys, Ann 2002, Freedom Ride: A freedom rider remembers, Allen \& Unwin, Sydney. 
confidence in the possibility of change'. Such qualities, however, we soon learn, apply only to white students. Arendt contrasts the 'disinterested and usually highly moral claims of the white rebels', whose 'student rebellion is a global phenomenon', with the Black Power movement on American campuses: 'Negro students, the majority of them admitted without academic qualification, regarded and organized themselves as an interest group, the representatives of the black community.' 'Their interest,' she adds disdainfully, 'was to lower academic standards.' In Arendt's contemptuous view, 'Negro demands' on universities are 'clearly silly and outrageous'. Black Power has introduced to the contemporary scene what she labels as serious violence and she reveals a curious note of what we might identify as white paranoia when she tells us that Black Power adherents entertain a 'dream world in which Negroes would constitute an overwhelming majority of the world's population'. Arendt feels that, lamentably, American university administrations have given in to Black Power violence, yielding to 'nonsensical and obviously damaging demands' such as the introduction of "soul courses" and instruction in Swahili', which she refers to in a note as a 'nineteenth-century kind of no-language spoken by the Arab ivory and slave caravans'. Arendt bases this assertion on the 'Encyclopaedia Britannica, 1961'. In the same endnote, she also condemns a Black Power demand for other 'nonexistent subjects' such as 'African literature'. ${ }^{80}$

In this contrast, then, the white rebels reveal an admirable interest in global moral concerns, addressing all of humanity, while Black Power is merely selfinterested and local. If we turn, however, to writing such as Stokely Carmichael and Charles V. Hamilton's 1967 book, Black Power: The politics of liberation in America, we quickly see that Arendt's characterisation of the movement - that it is incapable of universal moral values and vision - is bafflingly inaccurate and uncomprehending. In their preface, Carmichael and Hamilton say that they intend their book to be a contribution to the 'development of a viable larger society', which they see as possible only if white American society can be assisted to develop a historical consciousness shaped by 'clarity' and 'honesty' concerning how black people have been oppressed for centuries. ${ }^{81}$

In Black Power, we can see Carmichael and Hamilton engaging in a conversation with the early 1960s writings of Sartre and Fanon that seek to analyse the consciousness of the European colonisers and those colonised by Europe, asking how each can be transformed. In his 1961 preface to The Wretched of the Earth, Sartre had witheringly asked of his fellow Europeans that they should recognise that they all have benefited from 'the crime of colonialism'. Sartre invokes in particular the 'race murder', traumatising massacres (as at Sétif) and

80 Arendt, On Violence, pp. 15-19, 21n.37, 80, 96. Cf. Norton, 'Heart of darkness', pp. 249-52.

81 Carmichael, Stokely and Hamilton, Charles V. 1967, Black Power: The politics of liberation in America, Vintage, New York, pp. vii-viii. 
torture deployed by the French in Algeria on behalf of the European settlers, as a way of challenging the 'narcissism' of Europe and 'that super-European monstrosity, North America' ('Chatter, chatter: liberty, equality, fraternity, love, honour, patriotism and what have you'). Such a challenge must engage all Europeans, including Sartre himself: 'With us, to be a man is to be an accomplice of colonialism, since all of us without exception have profited by colonial exploitation.' Addressing 'my fellow-countrymen', Sartre reflects: 'It is not right...you who know very well all the crimes committed in our name, it's not right that you do not breathe a word about them to anyone, not even to your own soul, for fear of having to stand in judgement on yourself.' ${ }^{82}$

In their preface to Black Power, Carmichael and Hamilton take up the question of how to characterise white historical consciousness. 'Camus and Sartre have asked: Can a man condemn himself? Can whites, particularly liberal whites, condemn themselves? Can they stop blaming blacks and start blaming their own system? Are they capable of the shame which might become a revolutionary emotion?' Carmichael and Hamilton believe that it is black people themselves who must do such work of historical consciousness not only for themselves but for whites as well, and here they feel they are continuing the epistemological tradition of The Wretched of the Earth, including its internationalism. They see themselves as part of the Third World and that their struggle is 'closely related to liberation struggles around the world' - for example, in South Africa. In chapter two, 'Black Power: its need and substance', Carmichael and Hamilton suggest that a basic need for the oppressed in history is to challenge languagethe 'attempt by the oppressor to have his definitions, his historical descriptions, accepted by the oppressed'. This they also perceive as an international struggle. Thus black Africans have had to fight the white colonisers for the right to use the term 'Uhruru', meaning freedom. In American history, they note that in the wars between the "white settlers and the "Indians"', a battle won by the cavalry was described as a 'victory', whereas the military triumphs of the 'Indians' were called 'massacres'. Just as 'red men' had to be named 'as "savages" to justify the white men's theft of their land', so black men had to be vilified as 'lazy', 'apathetic', 'dumb' and 'shiftless'. Here they quote an amusing passage from Lewis Carroll on Humpty Dumpty assuming he is the master who can name things as he thinks fit. Black people, Carmichael and Hamilton contend, must take control of their own definitions: 'From now on, we shall view ourselves as African Americans and as black people who are in fact energetic, determined, intelligent, beautiful and peace loving. ${ }^{183}$

82 Sartre, Jean-Paul 1961, 'Preface', Frantz Fanon, The Wretched of the Earth, accessed 13 August 2010, http://www.marxists.org/reference/archive/sartre/1961/preface.htm

83 Ibid., pp. ix, xi, 35-8. 
Carmichael and Hamilton call for the development among black Americans of a 'new consciousness' of their history - a history that 'pre-dates their forced introduction' to America: 'African-American history means a long history beginning on the continent of Africa, a history not taught in the standard textbooks of this country.' They feel it is essential for black people to develop an 'awareness of their cultural heritage', for they have been too long kept submissive by being told that they had 'no culture, no manifest heritage' before they 'landed on the slave auction blocks'. Taking up a suggestion of John O. Killens' Black Man's Burden (1965), they argue that African Americans, in recognising their long history, can play an important role in the world as a bridge between the West and Africa-Asia, so making possible a human reconstruction once much of humanity is released from the ruthless grip of white supremacy. By helping create a 'new consciousness' in Africa-Asia, in fostering political modernisation by 'broadening the base of political participation to include more people in the decision-making process' and by opposing the 'racist system' that subtends 'middle-class America', African Americans can help create 'an open society' and, more generally, 'the expansion of humanity' ${ }^{84}$

In speaking for an open democratic society and the expansion of humanity as objectives of Black Power, Carmichael and Hamilton are situating their values and visions within a tradition of universal moral philosophy that is continuous with Martin Luther King jr, despite their moving away from King's Gandhian precepts of non-violence. Recall King's famous 'Letter from Birmingham Jail' of 16 April 1963, in which he relates his moral vision to the thinking of a wide array of world historical religious and philosophical figures. King writes that a concern for human rights must involve all humanity: 'Injustice anywhere is a threat to justice everywhere.' Here is a truth, King suggests, that was recognised by the 'prophets of the eighth century $\mathrm{BC}^{\prime}$ and by the Apostle Paul when he left 'his village of Tarsus and carried the gospel of Jesus Christ to the far corners of the Greco-Roman world'. The contemporary non-violent resister, King notes, is following in the footsteps of 'nonviolent gadflies' such as Socrates, stirring discussion so that people can submit 'myths and half-truths' to 'creative analysis'. We must recognise how difficult a process this is-Reinhold Niebuhr reminding us that 'groups tend to be more immoral than individuals', not least, in King's view, the white segregationist groups of the American South. We have to oppose unjust laws such as segregationist statutes, for did not St Augustine say that an unjust law is no law at all? Segregation, King observes, 'distorts the soul and damages the personality', and here he refers to Martin Buber's argument that in our ethical relations with others we must substitute an Ithou for an I-it relationship. History, King feels, is made by such independent thinkers - Socrates' civil disobedience leading to the academic freedom of today. 
King goes on to admire a concern for universal justice in figures such as Paul Tillich, Martin Luther, John Bunyan, Abraham Lincoln, Thomas Jefferson and T. S. Eliot. King also sees the struggle for civil rights in America in the wider context of the nations of Asia, Africa, South America and the Caribbean moving towards political independence. ${ }^{85}$

King's admiration for Socrates as gadfly - a provoker of discussion and creative analysis - could well apply to Arendt herself in her interest in the figure of the pariah. ${ }^{86}$ Clearly, however, Arendt could not recognise any thinking of value in African-American intellectual and cultural traditions. She could not see that a black liberation movement such as Black Power-like the other liberation movements of the late 1960s, including women's and gay rightswas encouraging and developing new thinking about race, gender, sexuality, colonialism and the post-colonial, as well as a massive expansion of university courses. In terms of historiography, such new thinking led to a diasporic awareness of many world histories, some of which might be related to Europe, others not, anticipating Janet Abu-Lughod's anti-Euro-centric world-history approach in her Before European Hegemony: The world system A.D. 1250-1350 (1989). ${ }^{87}$ Ironically, African-American intellectual traditions assisted, we might say, in the emergence of a post-colonial humanistic ethos, such as that advocated by Edward Said, by which Arendt and Lemkin would themselves come to be creatively analysed.

I agree, then, with Anne Norton's argument that Arendt's 'constructions of Africans and African Americans, her forgetfulness of Asians, and her efforts to sequester racism in the South' do not subvert or depart from what Arendt herself calls the common prejudices of Americans. Arendt, Norton points out, is following Hegel in regarding Africans and African Americans as outside world history. ${ }^{88}$ Ned Curthoys suggests that Arendt 'adjudges the real tragedy of colonialism as its abrogation of European humanism and republican values, rather than its invasion and displacement of existing indigenous cultures', and that, unlike Sartre in relation to Algeria, Arendt refuses to acknowledge 'those dimensions of colonialism and imperialism that constituted physical and cultural genocide'. In Curthoys' view, Arendt consistently fails to acknowledge the 'dignity and complexity of non-Western societies' and the 'subjectivity of non-

85 King, Martin Luther jr 2003 [1963], Why We Can't Wait, Signet, New York; 'Letter from Birmingham Jail', pp. 65, 67-72, 76-7, 82 .

86 See Curthoys, "The émigré sensibility of "world literature"”.

87 See Hofmeyr, Isabel 2007, 'The black Atlantic meets the Indian Ocean: forging new paradigms of transnationalism for the global south-literary and cultural references', Social Dynamics, vol. 33, no. 2 (December), pp. 3-32. On page 6, Hofmeyr refers to the millennia-long history of the Indian Ocean as an interregional arena, whose dominant written languages were Arabic, Persian, Gujarati and Swahili.

88 Norton, 'Heart of darkness', pp. 248, 252. 
Western peoples' ${ }^{89}$ In relation to other exiled European intellectuals in the United States, we might also think of Adorno and Horkheimer's notorious judgment in Dialectic of Enlightenment that jazz was a mere manifestation of nature - nature interacting with the demands of the American mass entertainment industries; Adorno and Horkheimer refer to jazz as stylised barbarity and non-culture. In these terms, Adorno and Horkheimer-and, it would very much appear, their contemporaries and fellow exiles Arendt and Lemkin-were conforming to a long tradition of European superiority and contempt towards Africa. Cosmopolitanism was defeated by profound persisting Euro-centrism. ${ }^{90}$

\section{The Cold War}

For Lemkin, then, in the late 1940s and 1950s, there was the ever-pressing Cold War context. Anton Weiss-Wendt suggests that from about 1949, Lemkin, in a desperate and futile attempt to get the United States to ratify the convention, increasingly aligned himself with the US side in the Cold War and accordingly adopted a strongly anti-communist stance. Furthermore, he became closely allied with, and financially supported by, particular organisations of Eastern European ethnic communities in the United States, who had enthusiastically adopted the new term 'genocide' in their denunciations of Soviet power and whom he advised for an exhibit titled 'Communism exterminates nations: exhibit of genocide in Lithuania' in $1951 .^{91}$

It was not only Lemkin for whom Cold War considerations were relevant in terms of the rejection of the We Charge Genocide petition. Such considerationswhich were to inflect most discussions of genocide from the 1950s to the 1980swere so strong in relation to the petition that they fuelled intra-racial divisions in the Black anti-racist struggle. When he presented We Charge Genocide to the United Nations in Paris, Patterson encountered opposition on Cold War grounds from African-American members of the American delegation to the

89 Ned Curthoys, 'The refractory legacy of Algerian decolonisation: revisiting Arendt on violence', in King and Stone, Hannah Arendt and the Uses of History, p. 125.

90 See Adorno, Theodor and Horkheimer, Max 1979, Dialectic of Enlightenment, London, Verso, pp. 1278; Docker, John 1994, Postmodernism and Popular Culture: A cultural history, Cambridge University Press, Melbourne, p. 38. Also: Rabinbach, 'The challenge of the unprecedented', p. 409. For a different perspective, focusing on the question of anti-Semitism, see Benhabib, Seyla 2009, 'From "the dialectic of enlightenment" to "the origins of totalitarianism" and the Genocide Convention: Adorno and Horkheimer in the company of Arendt and Lemkin', in Warren Breckman, Peter E. Gordon, A. Dirk Moses, Samuel Moyn and Elliot Neaman (eds), The Modernist Imagination: Intellectual history and critical theory essays in honor of Martin Jay, Berghahn, New York, pp. 299-330.

91 Weiss-Wendt, 'Hostage of politics', p. 555; Elder, 'What you see before your eyes', p. 488. 
UN Human Rights Commission, especially Channing Tobias, Edith Sampson and Ralph Bunche. ${ }^{92}$ (Eleanor Roosevelt headed the American delegation and was also chair of the UN Human Rights Commission.)

Horne in Black and Red also refers to Du Bois' dislike of 'certain Blacks' such as Tobias and Sampson who travelled to Third World countries on behalf of the State Department in order to rebut charges that the United States was racist towards people of colour. ${ }^{93}$ John D'Emilio in his biography of Bayard Rustin says that Rustin, a major African-American advocate of Gandhian non-violencewhile he condemned in the postwar years the assault on civil liberties that rightwing anti-communism inspired-stayed away from any involvement with the Civil Rights Congress 'because its policies mimicked the line of the Communist Party'. Rustin also advised a North Carolina pacifist not to invite Paul Robeson to give a concert in Chapel Hill because Robeson was closely identified with the Communist Party. ${ }^{94}$

\section{Conclusion}

In terms of Janet Abu-Lughod's world-history approach in her essay 'The world-system perspective in the construction of economic history' (1995), how should we assess Lemkin as a key thinker? Abu-Lughod writes that significant thought - including major transformations in how we think about the worldis inspired by eccentricity, a personal vision and a synthetic imagination. Here certainly Lemkin is a key thinker of world importance: he brought to world history a new concept and comparative perspective, transforming how we perceive the human condition and human history. Genocide as concept and law has inspired a whole field into existence - of genocide studies and, more recently, associated with it, massacre studies - and new international law concerned with protection of vulnerable groups and punishment of those who endanger their existence as groups, not only in the 1948 UN Convention but, later in the twentieth century, in new international legal bodies such as the International Criminal Court and tribunals to prosecute particular genocides.

Abu-Lughod urges world history to be anti-Euro-centric, and Lemkin, in a great deal of his work - published and unpublished - did write in far-reaching ways in an admirably anti-Euro-centric spirit valuing the oneness and diversity of humanity. We also remember, however, Lemkin's attitudes in relation to African Americans, Africa and Africans, especially his denunciation of the We Charge Genocide petition with its plea — a plea also made by Du Bois in his 1947 'Appeal

92 Patterson, The Man Who Cried Genocide, pp. 189-9; Horne, Communist Front?, pp. 172-3.

93 Horne, Black and Red, pp. 280-1.

94 D'Emilio, John 2003, Lost Prophet: The life and times of Bayard Rustin, Free Press, New York, pp. 178-9. 
to the world' - that the United Nations should recognise the plight of African Americans, in the South most desperately, but not confined to the South. ${ }^{95}$ Abu-Lughod refers to her own practice in Before European Hegemony to pair wherever possible evocations of the Crusades by Muslim and Christian writers: 'I was trying to de-center accounts, to view them ex-centrically.' ${ }^{96}$ Lemkinreminding us of Ned Curthoys' critique of Arendt that she consistently failed to acknowledge the dignity, complexity and subjectivity of non-Western peoples and societies - did not seek to know or understand or evoke African-American attitudes, viewpoints and consciousness. He also did not seek to de-centre common Cold War assumptions when he publicly repudiated the We Charge Genocide petition in The New York Times.

In the Introduction to Defying Dixie: The radical roots of civil rights, 1919-1950, Glenda Elizabeth Gilmore tells us that when she was growing up in the whitesupremacist South, in North Carolina, on family drives she would see roadside billboards declaring 'THIS IS KLAN COUNTRY, IMPEACH EARL WARREN, and US OUT OF THE UN'. ${ }^{97}$ In my view, when the creator of the genocide concept and the influential figure of the 1948 UN Genocide Convention spoke only a few years after 1948 against having the United Nations investigate whether American society was genocidal, he assisted the South - and the American society and institutions that historically supported it - to escape UN scrutiny and legal judgment. In effect, Lemkin lent his authority as a genocide expert to help maintain the South in its white supremacism, at the same time belittling those who courageously fought for civil rights. He also held back to this day, with rare exceptions, the field of genocide studies itself from scholarly investigation of African-American history in relation to genocide as concept and international law. Instead of - as Abu-Lughod's world-history methodology urges - keeping his society's pervasive beliefs, as in the bifurcatory terms of the Cold War, at a critical and self-reflexive distance, Lemkin succumbed to Cold War ideology, demeaning his own historical reputation.

I will not, however, end on a note of disappointment and disillusion. Rather, I will salute Lemkin as, for all the criticisms one might make, one of modern history's most interesting and creative thinkers, bringing into being a concept that calls into question the most fundamental questions: the character of humanity as a species, history as progress, the ethical bases of societies, the honour of civilisations and nations.

95 The full title of Du Bois' petition is 'An appeal to the world: a statement on the denial of human rights to minorities in the case of citizens of Negro descent in the United States of America and an appeal to the United Nations for redress'. See Gilmore, Defying Dixie, p. 408.

96 Abu-Lughod, 'The world-system perspective', pp. 91, 92, 94-6.

97 Gilmore, Defying Dixie, pp. 1-2. 
Humanities Research Vol XVI. No 2. 2010

When Lemkin died in New York on 28 August 1959, seven people attended his funeral. Most of his family had perished in the Holocaust. ${ }^{98}$ Yet he left a rich legacy, for genocide quickly proved to be a protean and productive if always contested concept.

98 Power, 'A Problem from Hell', pp. 78 and 535n.48. 